\title{
Some Results of the Treatment of Plantar Ulcers with Polybactrin and Cicatrin
}

\author{
I. A. SUSMAN, M.в., CH.в., D.P.H., D.т.м \& H. \\ Leprologist, Republic of Togo*
}

\section{INTRODUCTION}

The plantar ulcer is a condition only too well known to those working in the domain of leprosy. Treatment of such ulcers is a big problem especially to those working in the field and without all the necessary facilities of surgery, physiotherapy, shoe-making, etc., available.

That treatment is difficult is shown by the large number of different applications and forms of treatment listed in the various textbooks and numerous articles written on the subject. The treatments vary also according to the stage and severity of the lesion, including involvement of underlying bone. Complete rest and plaster casts are now well-tried methods of dealing with plantar ulcers. However, these are not really very practical for large numbers of patients who cannot be hospitalised or for whom the facilities for plastering do not conveniently exist. Similarly, orthopaedic or plastic surgical procedures can only be carried out at special centres. What is required for the majority of plantar ulcer sufferers is a treatment which can be carried out at home or at an out-patient clinic with little inconvenience to the patient himself and with little extra burden on the medical personnel.

The common sites of plantar ulceration are as follows:---

I and II metatarsal heads.

Tubercle at base $\mathrm{V}$ metatarsal.

The calcaneal tubercles at the heel.

The head of the proximal phalanx of the great toe.

The terminal phalanges of the toes.

Three of the major factors in the causation of plantar ulceration are sensory loss, motor loss, and vasomotor loss. Of these 3 factors, only the third lends itself to a possibility of practical correction in the field. Vaidyanathan ${ }^{1}$ has already reported on the usefulness of a vasodilator (nicotinic acid) in the treatment of plantar trophic ulcers. Given intravenously, it had a better effect than administered orally. Lauret and Kerbastard ${ }^{2}$ also attributed the good results they obtained in treating perforating ulcers to the vasodilatory action of the intraveous injections of dehydrocholate of sodium which they gave. Priscol has also been given by perineural injection causing trophic ulcers of the sole to heal with prolonged treatment-Mathur, Sehgal and Rao ${ }^{3}$.

It has been shown that topical applications of certain amino-acids can accelerate tissue healing and epithelialisation-Sullivan ${ }^{4}$, Brunsting and Simonsen ${ }^{5}$ - by their local absorption and utilisation causing an increased blood supply to the part stimulating cell proliferation - Neunhoeffer ${ }^{6}$, Bronner and Fargel ${ }^{7}$.

Griffiths $^{8}$ used both Cicatrin and Polybactrin to treat successfully 2 leprosy patients with large ulcers of the thigh and leg.

This paper is to indicate some results of a trial of Polybactrin and Cicatrin in the treatment of trophic plantar ulcers in leprosy patients.

\section{PHARMACOLOGY}

Polybactrin is an antibiotic powder, each g. of which contains:-

Neomycin Sulphate (as base) $330 \mathrm{mg}$.

Polymyxin 'B' Sulphate 100,000 units

Zinc Bacitracin 25,000 units

- pressurised with Dichlorotetrafluoroethane and Dichlorodifluoromethane.

\footnotetext{
* Until September 14th, 1967.
} 
Cicatrin is an amino-acid antibiotic powder or cream, each g. of which contains:-

$\begin{array}{ll}\text { Neomycin Sulphate } & 3.3 \mathrm{mg} \text {. base } \\ \text { Zinc Bacitracin } & 250 \mathrm{units} \\ \text { l-Cysteine } & 2 \mathrm{mg} . \\ \text { Glycine } & 10 \mathrm{mg} . \\ \text { dl-Threonine } & 1 \mathrm{mg} .\end{array}$

\section{METHOD}

Nine patients were chosen arbitrarily who had plantar ulceration of both feet, all of more than one year's duration. Five further patients were chosen with one foot only ulcerated but which was present for 6 years or more without complete healing. Amongst these 14 patients, 27 ulcers were taken into account plus one ulcer which developed later. Seventeen were treated and 11 untreated. The patients were residents of a leprosy village where there was no facility for hospitalisation.

The application of the medicaments was made twice weekly during the first 6 weeks and then once weekly during the next 7 weeks of the trial. A light gauze dressing and bandage were applied in each case. None of the patients was put at absolute rest but they were all asked to try not to do any unnecessary walking about during the period of treatment.

Those who had bilateral ulcers were given treatment for one foot only (the foot with the larger ulcer being chosen) and the other was dressed without any application of medicament.

Some of the ulcers were treated with either Polybactrin, Cicatrin powder or Cicatrin cream, and others with both Polybactrin and Cicatrin powder or Polybactrin and Cicatrin cream. The frequency of the medicaments used depended upon their availability.

Photographs of the ulcerated feet were taken on the day the treatment was commenced, on the 40th day and again on the 90th day of treatment.

\section{RESULTS}

The accompanying photographs show the results in 5 of the patients with bilateral ulceration and in the one patient with unilateral ulceration. This history and treatment is given with each photograph. The results of the other 8 patients with bilateral ulceration are also similarly presented although without photographs.

The results were classified according to the increase or reduction in size of the ulcers as follows:-

$\mathrm{BAD}$-Increase or no reduction.

FaIR-Reduction up to $45 \%$.

GooD-Reduction between $45 \%$ and $90 \%$.

ExCELlent-Reduction more than $90 \%$.

The results are summarised in Table 1 .

It can, therefore, be seen that all the ulcers which were not treated with the drugs under trial increased in size after 40 days except 2 which remained stationary (Patients 915 and 1102) and 2 which showed some decrease $(24.2 \%$ in Patient 889 and $17 \%$ in Patient 569$)$. In Patient 807, a new ulcer was formed during the first 40 days of treatment and this showed an increase in size after 90 days. In addition, after 90 days, only one remained stationary (Patient 915), whilst Patient 1102 now showed an increase in size of the untreated ulcer. Also, at this time, Patients 889 and 569 continued to show a diminution in size of the untreated ulcers of $43.2 \%$ and $17 \%$ of the areas, respectively. Patient 108's ulcer which had increased after 40 days had diminished by $24.4 \%$ after 90 days (without treatment).

Thus, no treatment produced 9 'bad' and 2 'fair' results after 40 days and 8 'bad' and 3 'fair' results after 90 days.

In the treated ulcers, though the healing in most cases was not complete, except in Patients 915 and 569 after 40 days, and in addition in Patients 1102 and 807 after 90 days, the marked improvement in nearly all the patients treated with Polybactrin and Cicatrin, especially the latter, has prompted the presentation of this paper. In fact, the treated ulcers provided 9 'fair', 2 'good' and 6 'excellent' results after 40 days and then only 1 'bad', 5 'fair, 4 'good' and 7 'excellent' results after 90 days. Most of the ulcers treated also showed a decrease in 
TABLE I

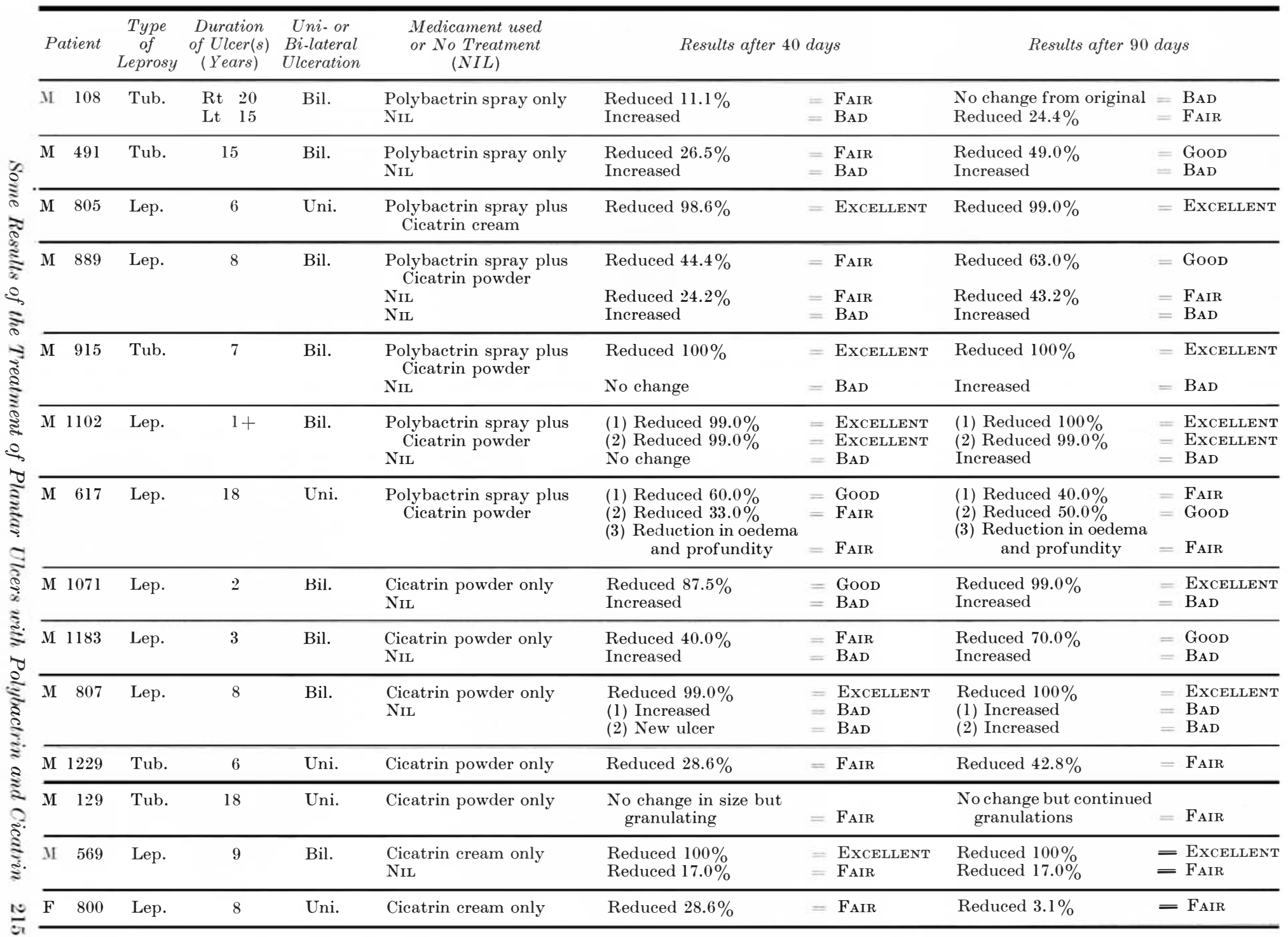




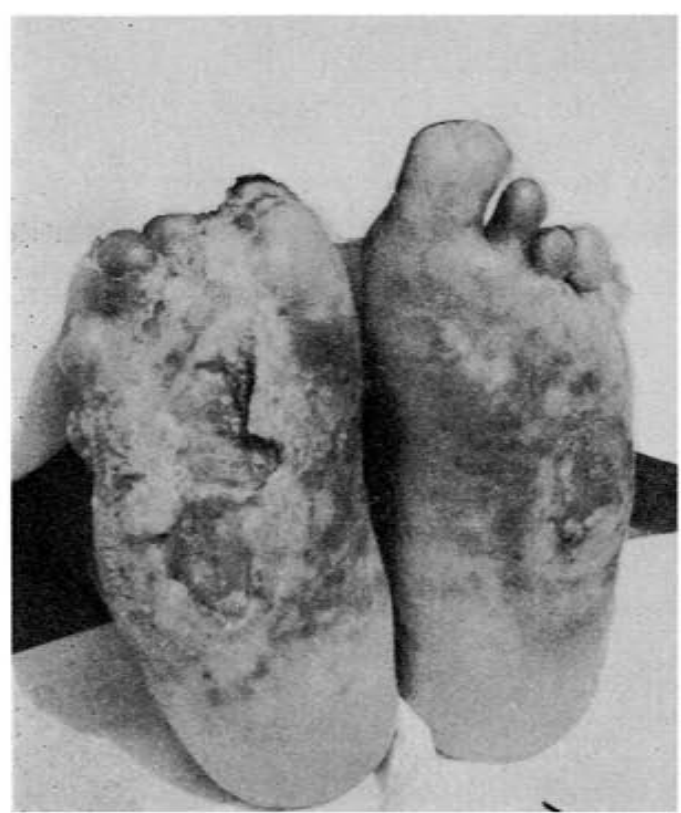

30th March 1967

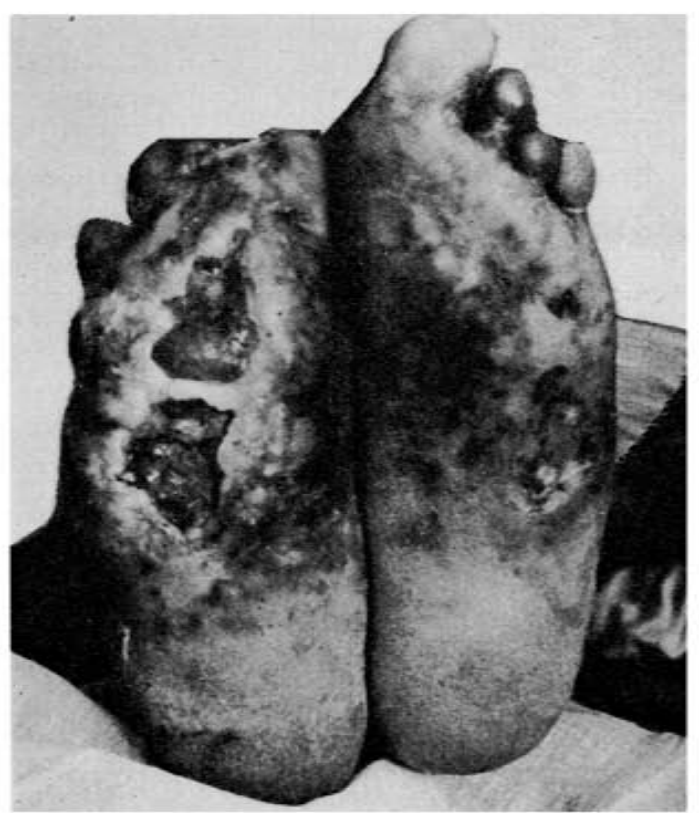

8th May 1967

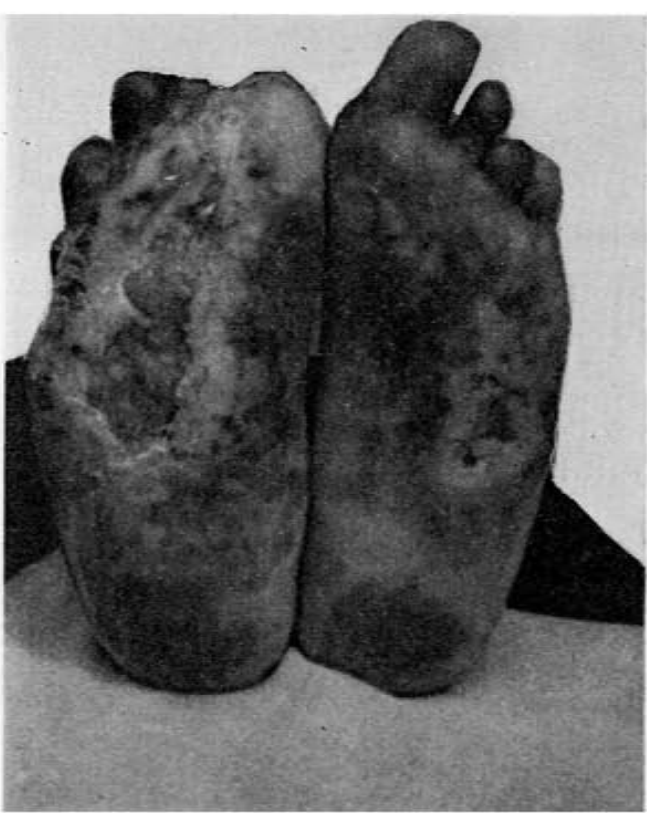

28th June 1967

Patient 108: Male. 60 years. Tuberculoid. Admitted 1951. History of ulcers: Right 20 years, Left 15 years.

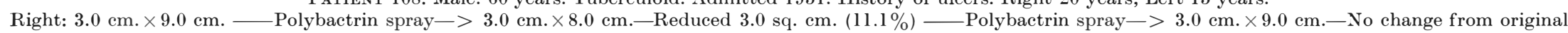
Left: $1.7 \mathrm{~cm} . \times 3.5 \mathrm{~cm} . \longrightarrow$ Nil $\longrightarrow 1.7 \mathrm{~cm} . \times 3.8 \mathrm{~cm} .-$ Increased $0.51 \mathrm{sq} . \mathrm{cm} . \longrightarrow$ Nil $\longrightarrow>1.5 \mathrm{~cm} . \times 3.0 \mathrm{~cm} .-$ Reduced $1.45 \mathrm{sq} . \mathrm{cm} .(24.4 \%)$

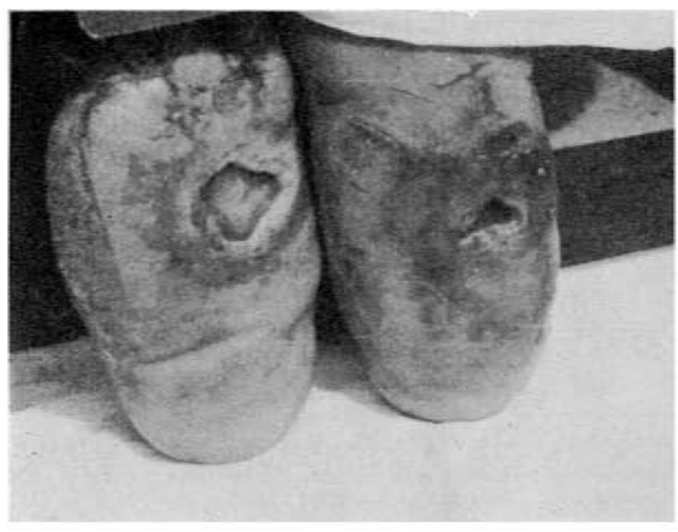

30th March 1967

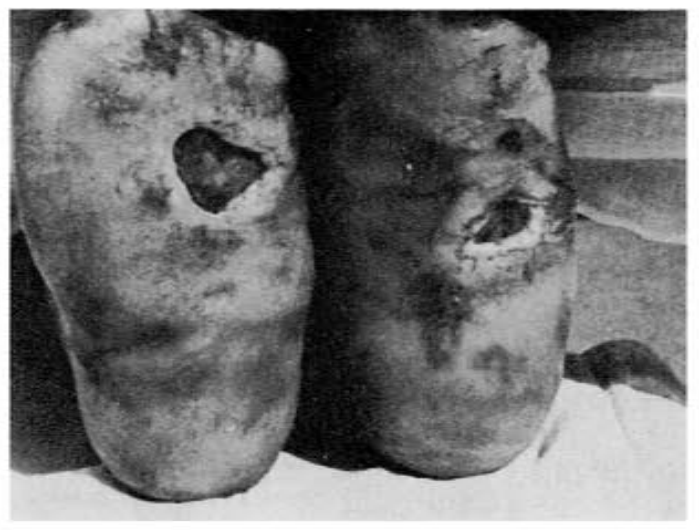

9th May 1967

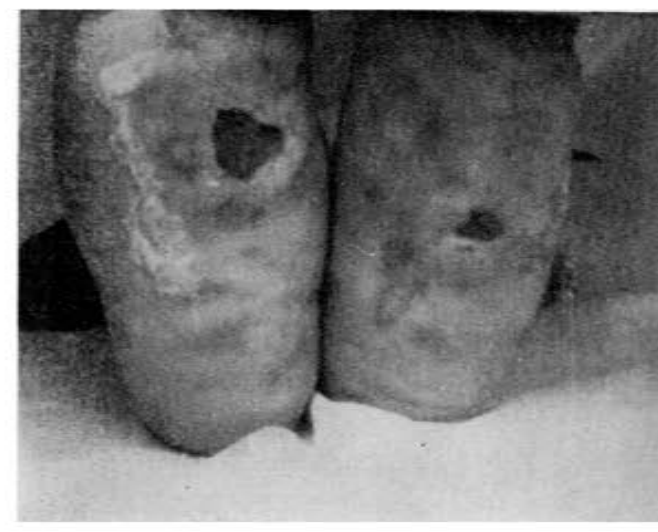

28th June 1967

Patient 491: Male. 40 years. Tuberculoid. Admitted 1964. History of ulcers: 15 years.

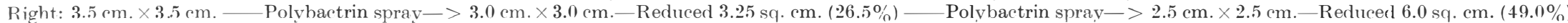
Left: $\quad 0.6 \mathrm{~cm} . \times 2.3 \mathrm{~cm} . \longrightarrow$ Nil $>0.8 \mathrm{~cm} . \times 2.3 \mathrm{~cm}$. - Increased $0.46 \mathrm{sq} . \mathrm{cm} . \longrightarrow$ Nil $\longrightarrow>1.0 \mathrm{~cm} . \times 1.5 \mathrm{~cm} .-\mathrm{Increased} 0.12 \mathrm{sq} . \mathrm{cm}$. 


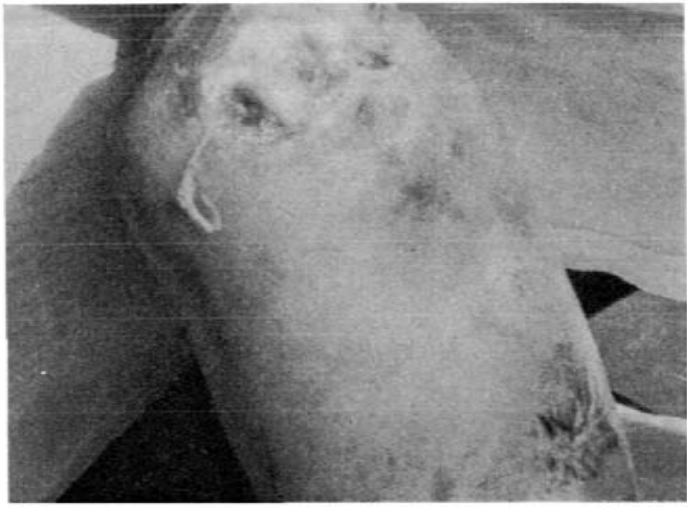

30th March 1967

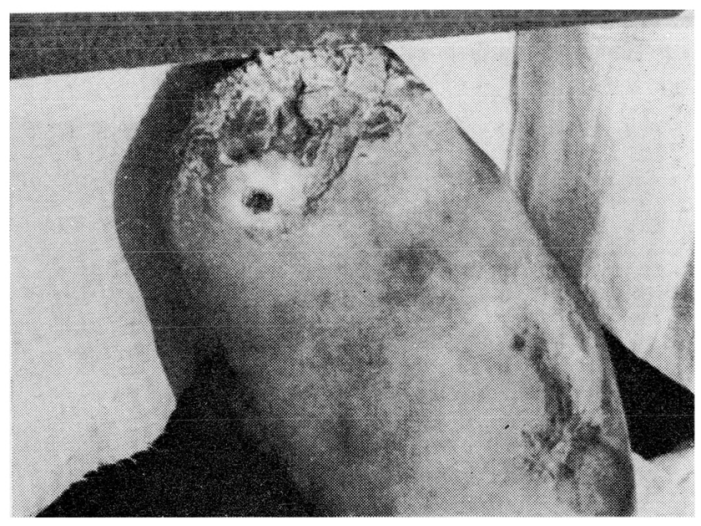

8th May 1967

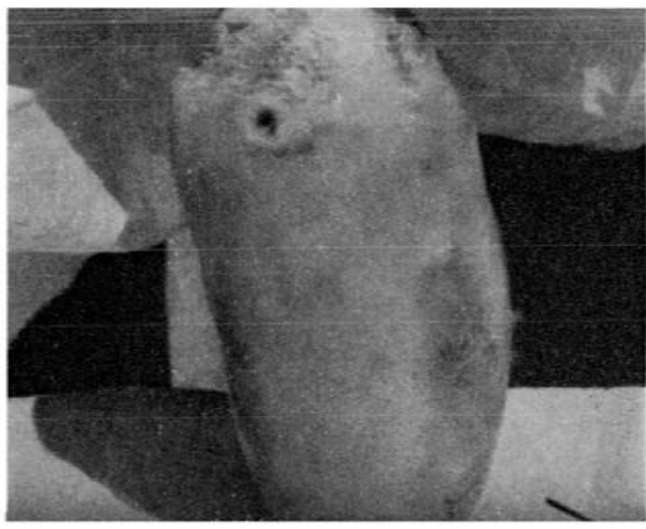

28th June 1967

Patient 805: Male. 67 years. Lepromatous. Admitted 1952. History of ulcer: 6 years.

Right: $5.8 \mathrm{~cm} . \times 3.0 \mathrm{~cm} . \longrightarrow$ Polybactrin spray plus Cicatrin cream $\longrightarrow 0.5 \mathrm{~cm} . \times 0.5 \mathrm{~cm} .-$ Reduced $17.15 \mathrm{sq} . \mathrm{cm} .(98.6 \%) \longrightarrow$ Polybactrin spray plus Cicatrin cream $\longrightarrow>$ $0.4 \mathrm{~cm} . \times 0.4 \mathrm{~cm}$. - Reduced $17.24 \mathrm{sq} . \mathrm{cm} .(99.0 \%)$

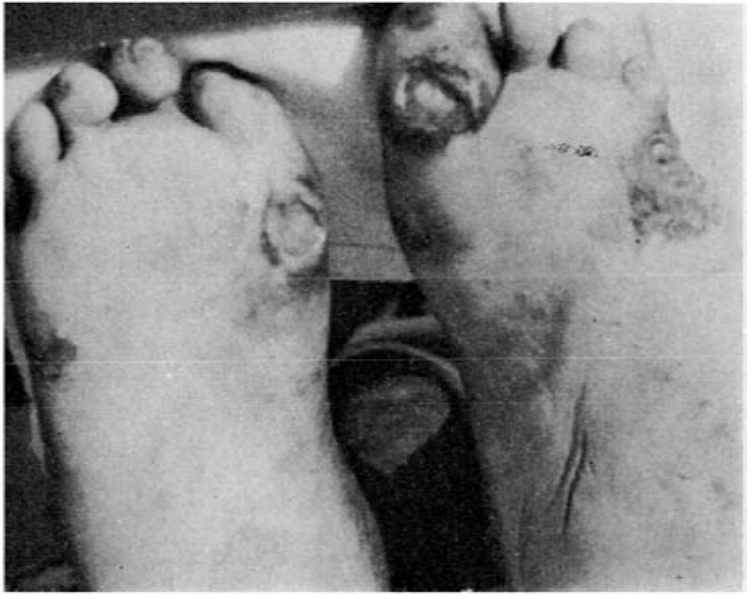

30th March 1967

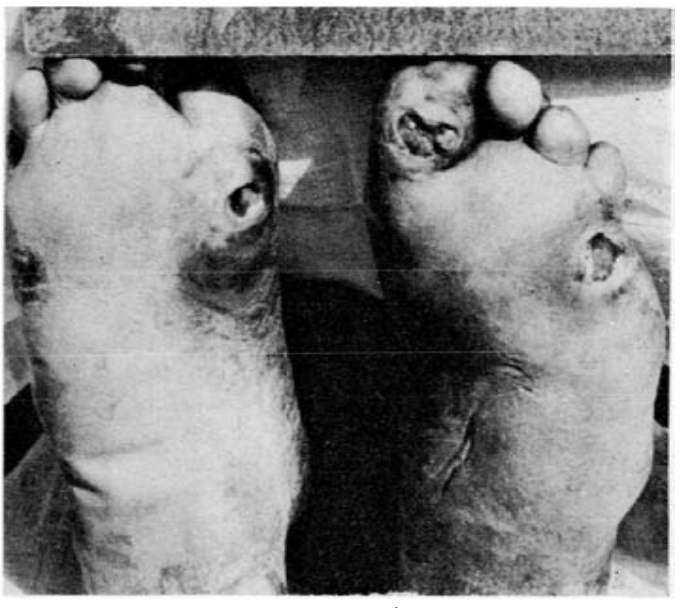

2 May 1967

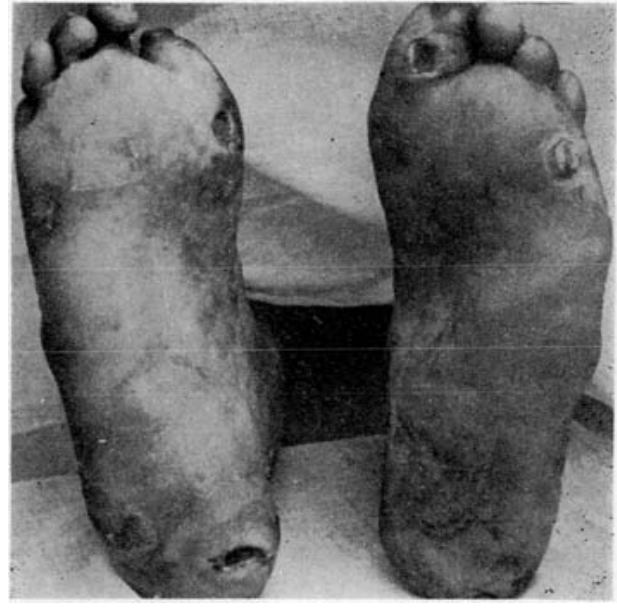

28th June 1967

Patient 889: Male. 42 years. Lepromatous. Admitted 1955. History of ulcers: 8 years.

Right: $1.8 \mathrm{~cm} . \times 1.8 \mathrm{~cm}$. $\longrightarrow$ Polybactrin spray plus Cicatrin powder $\longrightarrow 1.5 \mathrm{~cm} . \times 1.2 \mathrm{~cm}$. - Reduced 1.44 sq. cm. $(44.4 \%) \longrightarrow$ Polybactrin spray plus Cicatrin powder $\longrightarrow>$

Left: $\quad 2.2 \mathrm{~cm} . \times 1.2 \mathrm{~cm}$. (gt. toe) $\longrightarrow$ Nil- $>2.0 \mathrm{~cm} . \times 1.0 \mathrm{~cm}$. -Reduced $0.64 \mathrm{sq} . \mathrm{cm} .(24.2 \%) \longrightarrow \mathrm{Nil} \longrightarrow>1.5 \mathrm{~cm} . \times 1.0 \mathrm{~cm} .-$ Reduced $1.14 \mathrm{sq} . \mathrm{cm} .(43.2 \%)$ $0.5 \mathrm{~cm} . \times 0.5 \mathrm{~cm} .(4 \mathrm{th} \mathrm{mt}.) \longrightarrow$ Nil $\longrightarrow 1.5 \mathrm{~cm} . \times 1.2 \mathrm{~cm}$. -Increased $1.55 \mathrm{sq} . \mathrm{cm} . \longrightarrow$ Nil $\longrightarrow 1.0 \mathrm{~cm} . \times 0.5 \mathrm{~cm} .-$ Increased $0.25 \mathrm{sq} . \mathrm{cm}$. 


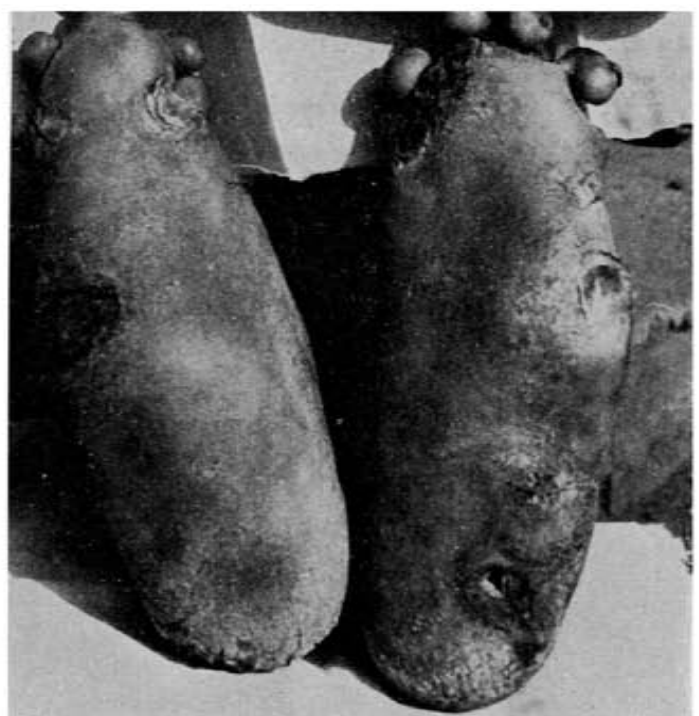

9th May 1967

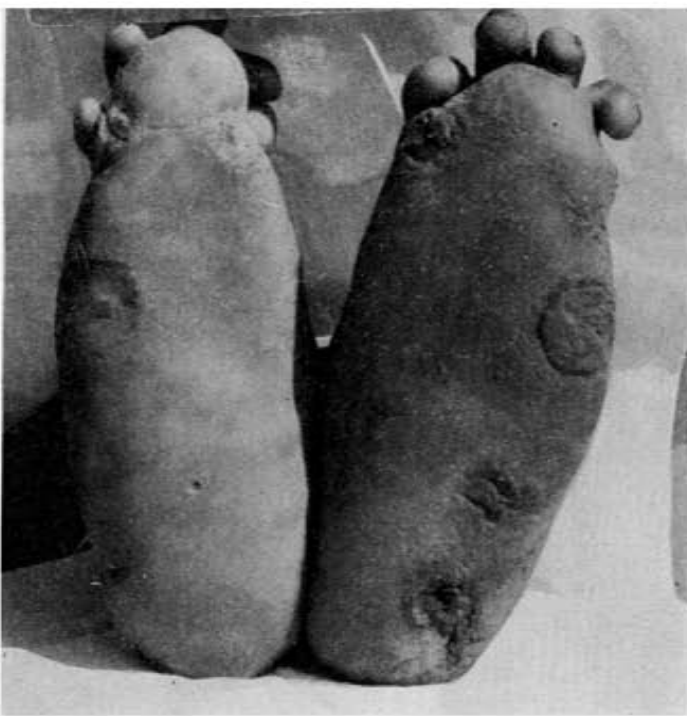

28th June 1967

Patient 915: Male. 52 years. Tuberculoid. Admitted 1956. History of ulcers: 7 years.

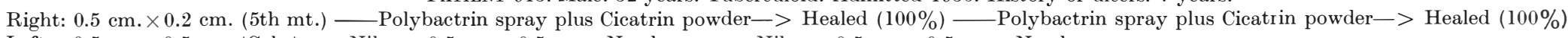
Left: $0.5 \mathrm{~cm} . \times 0.5 \mathrm{~cm}$. (Calc.) $\longrightarrow$ Nil $\longrightarrow 0.5 \mathrm{~cm} . \times 0.5 \mathrm{~cm} .-\mathrm{No}$ change $-\mathrm{Nil} \longrightarrow 0.5 \mathrm{~cm} . \times 0.5 \mathrm{~cm} .-\mathrm{No} \mathrm{change}$

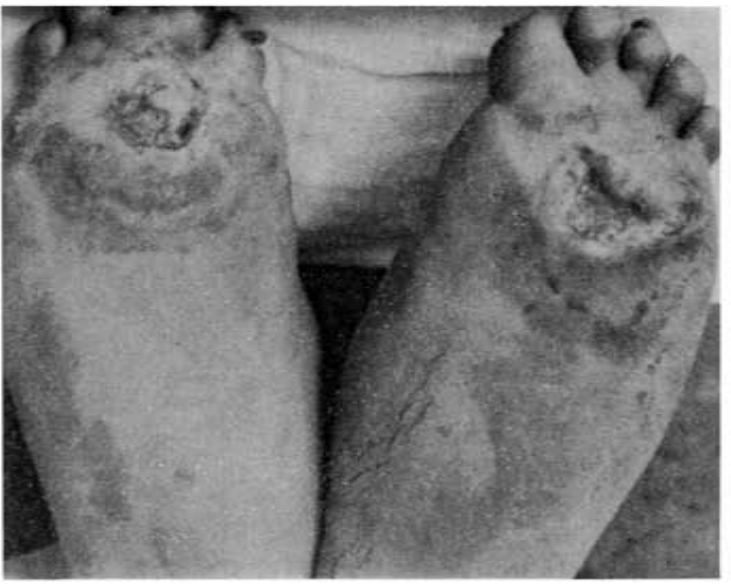

30th March 1967

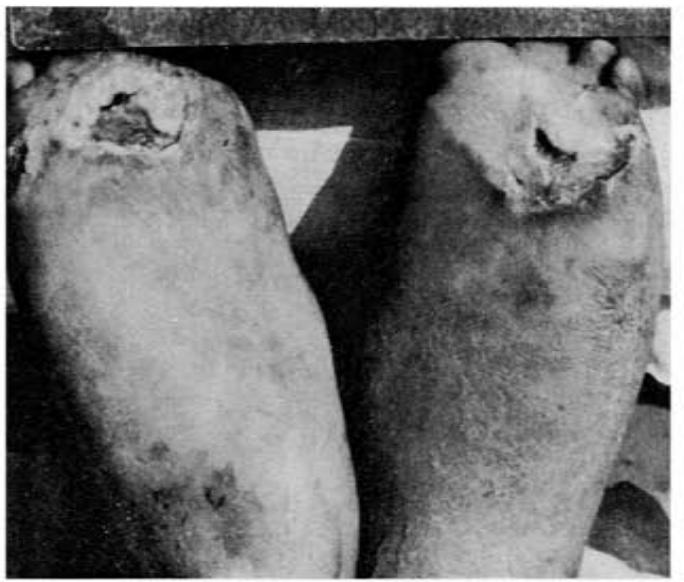

9th May 1967

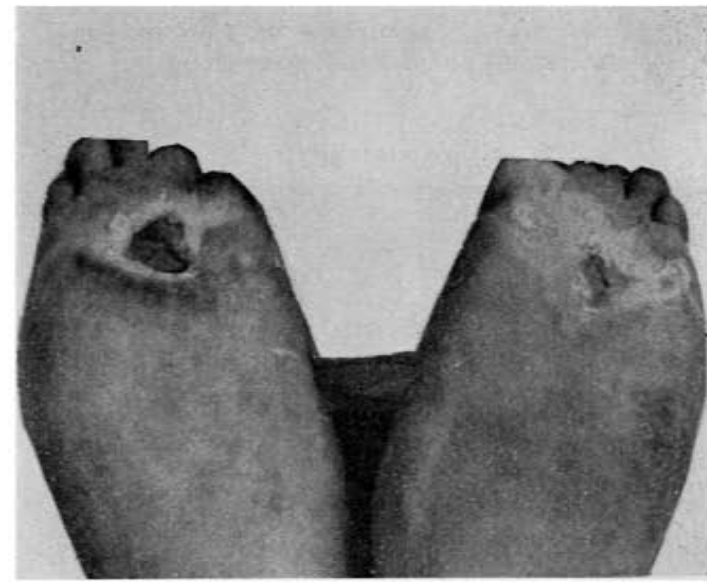

28th June 1967

Patient 1071: Male. 25 years. Lepromatous. Admitted 1961. History of ulcers: 2 years.

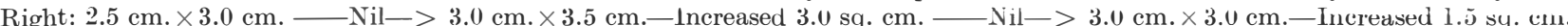

Left: $4.0 \mathrm{~cm} . \times 2.0 \mathrm{~cm} . \longrightarrow$ Cicatrin powder $\longrightarrow>1.0 \mathrm{~cm} . \times 1.0 \mathrm{~cm} .-$ Reduced $7.0 \mathrm{sq} . \mathrm{cm} .(87.5 \%) \longrightarrow$ Cicatrin powder- $>$ Almost healed $(99.0 \%)$ 
depth after 40 days and this improvement continued.

All the patients themselves were very enthusiastic about the treatment, being delighted with the amount of progress made in the healing of their ulcers within the space of some few weeks, whereas previously they had shown no sign of improvement during several years.

All the patients continued on their normal dosage of Dapsone during the ulcer treatments.

\section{DISCUSSION}

One of the most difficult problems in the treatment of leprosy patients is the specific treatment of plantar ulcers. Surgery and special footwear play an important part but facilities for their provision are not always possible.

Within the limitations of this trial, there were indications that Polybactrin spray, Cicatrin powder and Cicatrin cream can produce promising results in the healing of trophic plantar ulcers in leprosy patients, even those ulcers of very long standing. In the above series, it appeared that Polybactrin spray combined with Cicatrin powder or cream gave the best results, whereas Polybactrin spray on its own gave the less promising results. Cicatrin powder or Cicatrin cream alone also produced very good results. These results can be tabulated as follows:-
Hence, after 40 days of one of the above treatments, there were no 'bad' results, $52.9 \%$ were 'fair', $11.8 \%$ were 'good' and $35.3 \%$ were 'excellent'. After 90 days treatment, 5.9\% (one patient) showed a 'bad' result, $29.4 \%$ were 'fair', $23.5 \%$ were 'good' and $41.2 \%$ showed 'excellent' results.

Of course, one must not lose sight of the fact that once ulcers are healed, great care must be taken to prevent a recurrence. Thus, the application of whatever medicaments does not obviate the need for the provision of special shoes for all such healed feet.

Furthermore, one cannot emphasise too strongly or too often that 'prevention is better than cure'.

And finally, the cost of the drugs employed must at present be a factor limiting their widespread use.

\section{SUMMARY}

Nine leprosy patients with plantar ulceration of both feet and 5 with unilateral ulceration were chosen for treatment with Polybactrin spray, Cicatrin powder and Cicatrin cream. In those with bilateral ulceration, only one foot was treated. Seventeen ulcers were treated in all. The results after 6 weeks and then 13 weeks of treatment are presented. All the ulcers treated, except one, showed definite improve-

Results of 17 ulcers treated:

\begin{tabular}{|c|c|c|c|c|c|c|c|c|c|c|c|}
\hline & & & & \multicolumn{2}{|c|}{$B A D$} & \multicolumn{2}{|c|}{$F A I R$} & \multicolumn{2}{|c|}{$G O O D$} & \multicolumn{2}{|c|}{$E X C E L L E N T$} \\
\hline & & & & $\begin{array}{c}\text { After } \\
40 \text { days }\end{array}$ & $\begin{array}{c}\text { After } \\
90 \text { days }\end{array}$ & $\begin{array}{c}\text { After } \\
40 \text { days }\end{array}$ & $\begin{array}{c}\text { After } \\
90 \text { days }\end{array}$ & $\begin{array}{c}\text { After } \\
40 \text { days }\end{array}$ & $\begin{array}{c}\text { After } \\
90 \text { days }\end{array}$ & $\begin{array}{c}\text { After } \\
40 \text { days }\end{array}$ & $\begin{array}{c}\text { After } \\
90 \text { days }\end{array}$ \\
\hline Polybactrin spray only & $\cdots$ & $\cdots$ & . & 一 & 1 & 2 & - & - & 1 & - & - \\
\hline Polybactrin spray plus Ci & atrin & eam & $\cdots$ & - & - & - & - & - & - & 1 & 1 \\
\hline Cicatrin powder only & . & $\cdots$ & $\cdots$ & 一 & 一 & 3 & 2 & 1 & 1 & 1 & 2 \\
\hline \multirow[t]{2}{*}{ Cicatrin cream only .. } & $\cdots$ & $\cdots$ & $\cdots$ & - & - & 1 & 1 & - & 一 & 1 & 1 \\
\hline & & & & - & 1 & 9 & 5 & 2 & 4 & 6 & 7 \\
\hline
\end{tabular}


ment. After 90 days, 7 of the ulcers in this paper (that is, $41.2 \%$ ) showed excellent results (between $90 \%$ and $100 \%$ reduction in size), especially taking into the account the fact that all these ulcers were chronic of very long duration.

Although these drugs appear to be encouraging in the treatment of plantar ulcers in leprosy patients, they are not the last word in such treatment by a long way! Also, the cost of such drugs for local application must be a prohibitive factor. However, they appear to be worthy of further trials.

\section{ACKNOWLEDGEMENTS}

I am very grateful to Calmic Ltd., Crewe, Cheshire, for supplying the Polybactrin and Cicatrin for this trial. I am also grateful to my ward, Frank Elliott, for the taking and provision of all the photographs.

\section{REFERENCES}

1. Vaidyanathan, E. P. Trial of a Vasodilator on Trophic Ulcers. Lep. Rev. (1961), 32, 3, 144-149.

2. LAURet, L. and kerbastard, P. Treatment of Ulcerating Fissures and Perforating Ulcers with a Combination of Trichlor-acetic Acid and Salicylic Acid. Med. Trop. Marseilles (1956), Jan.-Feb., 16, $1,83-92$.

3. Mathur, J. S., Sehgal, v. N. and RAO, N. S. N. Perineural Priscol Injections in Leprosy Ulcers. Lep. Rev. (1966), 37, 4, 249-253.

4. suldivan, M. X. Sulphur and Cysteine in Vital Activities. Med. Ann. D.C.I., 125 (1932).

5. BRUnSting, L. A. and Simonsen, D. G. Cutaneous Ulcers Treated by Sulphydryl containing AminoAcid Cysteine. J. Amer. Med. Ass. (1933), 101, 1937.

6. NEUNHOEFFER, o. Influence of Glycocoll on Wound Healing. Dtsch. Gesundh.-Wes. (1947), 2, 311.

7. BRONNER, H. and FARGEL, H. Local Therapy with Amino-acetic Acid. Munch. med. Wschr. (1951), 93, 602 .

8. GRIfFiths, P. GLYN. Notes on the Treatment of Ulcers in Leprosy Patients with Polybactrin. Lep. Rev. (1966), 37, 4, 227-229. 